\title{
PERCEPTION OF CORRUPTION, PERCEPTION OF TAX COMPLEXITY, AND FINANCIAL INFORMATION ACCESS: EXTENDING THE ANALYSIS OF THE SLIPPERY SLOPE FRAMEWORK
}

\author{
Mardhiah \\ Directorate General of Taxes, Ministry of Finance of Indonesia \\ E-mail:mardhiah@pajak.go.id and mardhiah.4@gmail.com
}

\section{ABSTRACT}

Tax literature indicates the perception of corruption and perception of tax complexity as tax compliance factors. Nevertheless, although the initial Slippery Slope Framework (SSF) theory suggests several tax compliance factors to have associations with trust in and power of tax authorities, none of the SSF studies pay their attention to these two factors. Therefore, based on survey questionnaires on 500 individual taxpayers in Jakarta, Indonesia, as well as interviews on several taxpayers and key officers in the Directorate General of Taxes (DGT), this study is dedicated to elaborating the associations between these factors and trust and power and how the change in financial information access affects them. Mixed methods research was used through surveying individual taxpayers; and interviewing both individual taxpayers and tax officers. The results show that the factors are proven to significantly influence trust in and power of tax authorities, even though there is no significant association between perception of tax complexity and power. The results also confirm the main SSF assumptions that trust leads to voluntary compliance while voluntary compliance positively affects overall tax compliance. Yet, the study fails to evince the relationship of power to enforced compliance, while enforced compliance negatively affects overall tax compliance. 


\section{INTRODUCTION}

Despite efforts and policies implemented to improve Indonesia's tax system, the perception of corruption and tax complexity still become significant issues that hinder Indonesia in improving the tax compliance level. Corruption in Indonesia is even perceived to be pervasive and widespread in all sectors of society (Newman, 2011). Transparency International (2017) categorises Indonesia as a developing country with a high level of corruption. In the same vein, taxpayers still concern about tax complexity and long bureaucracy issues when dealing with the tax office. Some reasons are believed to cause these issues, such as the inability of the Directorate General of Taxes (DGT) to reach unregistered taxpayers in the tax system and to access complete financial information even on registered taxpayers.

Therefore, to reduce the possibility of corruption and promote tax simplicity, a substantial reform in the tax system was conducted by enacting Law 9/2017 on financial information access for taxation purposes. This act enables the DGT to access taxpayers' financial information owned by financial institutions and enhances the power of the DGT to collect taxpayers' offshore financial data through an Automatic Exchange of Information (DGT, 2017).

This paper aims to examine tax compliance factors that are believed to have associations with trust in and power of the tax authority, focusing on the perception of corruption and perception of tax complexity, and their relationship with the enactment of Law 9/2017 on financial information access for taxation purposes. These two factors are then considered in the Slippery Slope Framework (SSF) by linking them to trust and power in a relationship suggested by Kirchler et al. (2008). The relationship between these two factors and the enactment of Law 9/2017 is further discussed in the interview section.

Using Indonesia as the research place, this study provides new insights to better understand tax compliance and its determinants. The remaining sections are as follows. In section 2, we present a literature review. Section 3 discusses the hypotheses development. Section 4 presents data and methodology, while in Section 5, we discuss the results. Last, the final section provides conclusions.

\section{LITERATURE REVIEW 2.1 Perception of Corruption}

There are two categories of corruption, namely grand corruption and petty corruption (Doig \& Theobald, 1999). Grand corruption refers to the misuse of power by state leaders for their own benefit or the benefit of affiliations related to them (Doig \& Theobald 1999). This type of corruption mostly deals with high-level individuals and involves a large amount of money. Meanwhile, petty corruption is usually in the form of a small payment and mostly happens in administrative offices in the form of unofficial tips to ease access to government service they provide. Despite involving small amounts of money, Doig and Theobald (1999) argue 
that small corruption is just as significant as grand corruption because it impacts mostly on the poorest and weakest people in the society.

Regarding the perception of corruption, tax literature identifies a relationship between the perception of corruption and tax compliant behaviour (Feld \& Torgler, 2008; Melgar, Rossi, \& Smith, 2010; Torgler, 2004). A study by Torgler (2006) shows that a higher degree of perceived corruption influences tax compliance because taxpayers will feel cheated if they believe that corruption is commonly happening. This feeling will reduce their motivation to pay taxes. Moreover, Uslaner (2005) argues that the level of perception of corruption has a positive correlation with the level of tax evasion.

For the relationship between corruption and trust or power, existing tax literature identifies the association between them. Some studies indicate that the level of corruption has a negative relationship with political trust (Mishler \& Rose, 2001). Bird and Martinez-Vazquez (2008) argue that a high level of corruption is likely to erode public trust towards the government, and voluntary compliance will be hardly present. Richey (2010) argues that corruption reduces social trust because governmental corruption may make society seem untrustworthy. Meanwhile, Mishler and Rose (2001) in their study on ten post-communist countries in Eastern and Central Europe and the former Soviet Union, shows that the effect of corruption on trust would be reduced to insignificance once adequate systems supporting the legitimacy of the authority were taken. Similarly, a study by Seligson (2002) in four Latin American countries shows that corruption brings several impacts on government legitimacy.

\subsection{Perception of Tax Complexity}

Even though tax simplicity is commonly desirable, a clear and unambiguous regulation that accommodates all situations will be difficult to design (Carter, 1979). Yet, a simple law applied to complex situations is likely to give undesirable results (Bardach \& Kagan, 1982). Therefore, to get maximum results, there is a limit in a rule to be appropriately applied in a complex situation without it becoming too sophisticated to understand by both the regulator and the citizen (Scholz, 1984).

The existing tax literature shows the relationship between perception of tax complexity and tax compliance. Andreoni et al. (1998), for instance, propose several issues around the complexity of tax rules that may lead to non-compliant behaviour. They contend that vague and ambiguous regulations burden taxpayers, albeit willing to comply. They also argue that too detailed tax regulations are challenging to learn and follow. Furthermore, they highlight the impact of tax complexity affect not only taxpayers but also the performance of tax officers. The lack of knowledge amongst tax auditors on complex tax laws could cause incorrect tax assessments (Andreoni et al., 1998). Moreover, Richardson (2006) argues that the lower the level of complexity, 
the lower the tax evasion level. On the other hand, an increase in bureaucracy is associated with increased tax evasion (Riahi-Belkaoui, 2008). Besides, Saad (2011) argues that tax complexity is a contributing factor towards non-compliant behaviour, whether intentionally or unintentionally.

\subsection{The Slippery Slope Framework}

The Slippery Slope framework (SSF) has been introduced by Kirchler et al. (2008) that utilises a combination of economic and behavioural approaches in understanding tax compliance. The SSF investigates tax compliance by identifying the taxpayer's motivation in paying tax, whether voluntarily or enforced. The framework suggests that economic factors such as audit probabilities and tax penalties as well as behavioural factors (tax knowledge, attitudes, norms, distributive fairness, procedural fairness, and retributive fairness) measure trust in and power of tax authorities. According to the framework, trust in tax authorities is believed to become a significant predictor of voluntary compliance. In contrast, the power of tax authorities leads to enforced tax compliance.

Since its introduction, the SSF has theoretically and empirically developed. The SSF theory expands to the interactions between power and trust (Muehlbacher \& Kirchler, 2010) and the recognition of the different types of trust and power (Gangl et al., 2012; Gangl et al., 2015; Prinz et al., 2014). Meanwhile, Lisi (2012) proposes a different perspective in understanding the SSF that trust in tax authorities affects a firm's decision to evade taxes, and in turn, affects the unemployment rate. The study also suggests that a combination of deterrence and deference policy tools is essential to increase tax compliance.

Following the theoretical development, several empirical studies have been conducted to prove the assumption of the SSF. However, most of them focus on trust and power and their interactions with voluntary compliance and enforced compliance (Hofmann et al., 2014; Hofmann et al., 2017; Mas'ud et al., 2014; Muehlbacher \& Kirchler, 2010; Wahl et al., 2010). Only a few studies pay their attention to tax compliance factors believed to have associations with trust and power. For example, Kogler et al. (2013; 2015) test the SSF assumptions by considering several factors like perception of fairness, deterrence (penalty), and social norms. Another example comes from Gobena and Dijke (2016), which focus on procedural fairness. Meanwhile, Kasper et al. (2015) offer a different approach in elaborating the relationship between trust and power by examining the influence of mass media on trust and power. A study by Mardhiah et al. (2019) comprehensively elaborate tax compliance factors related to trust and power, such as audit probabilities, tax penalties, tax knowledge, attitudes, norms, and fairness. Further, the study differentiates fairness into distributive fairness, procedural fairness, and retributive fairness. The results show that most factors had a significant influence on trust and power. Also, trust leads to voluntary 
compliance and voluntary compliance in turn positively affects overall tax compliance (Mardhiah et al., 2019). Siahaan (2012) investigates the associations between perceptions of fairness, trust, and voluntary tax compliance in an Indonesian context. The study finds a positively significant direct effect of tax fairness on voluntary compliance. It also indicates a significant and positive indirect effect of tax fairness on voluntary compliance while including trust as a predictor.

\subsection{Financial Information Access for Taxation Purposes}

Aiming at enhancing the compliance level of taxation, in 2017, the Indonesian Government conducted a substantial reform in the tax system by issuing a Government Regulation in Lieu of Law (Peraturan Pemerintah Pengganti Undang-Undang) 1/2017 on financial information access for taxation purposes, which was enacted as a law through Law 9/2017. This regulation was issued to strengthen the DGT's position in accessing financial information from financial institutions. It enables the DGT to access taxpayers' financial information owned by financial institutions in banking, capital market, insurance, other financial service sectors, and/or other entities.

The enactment of this law revoked several articles in other laws which are related to financial information access. It eliminated bank secrecy in previous laws (for example, General Tax Provision Law 6/1983 as lastly amended by Law 16/2009, Banking Law 7/1992 as lastly amended by Law 10/1998, and Sharia Banking Law 21/2008), which obligated the DGT to follow lengthy procedures to access taxpayers' financial information and limited the access solely for tax audit, collection, and tax crime investigation of a particular taxpayer. It also revoked some articles in the Capital Market Law 8/1995 and the Commodity Futures Trading Law 32/1997 as last amended by Law 10/2011, which regulated the secrecy obligation on relevant parties in the capital market and commodity futures trading markets.

Moreover, this law allows the DGT to immediately access taxpayers' financial data without any obligation to obtain written approval from the Minister of Finance. This broad access to financial information made it easier for the DGT to detect undeclared assets during the tax amnesty program (which was conducted earlier) and to increase the power of the DGT in handling non-compliant behaviour.

\section{HYPOTHESES DEVELOPMENT}

Among the existing empirical SSF studies, only a limited number of them pay attention to elaborate tax compliance factors with trust and power associations. Furthermore, regardless of the relationships between perception of corruption and tax complexity and tax compliance, these two factors are apparently not discussed in the SSF research. Therefore, this study is dedicated to extending the SSF framework analysis by focusing on the two factors in the SSF. To examine 
the associations between these two factors and trust and power, two hypotheses are developed where each hypothesis consists of two sub-hypotheses:

Hypothesis 1a: Perception of corruption significantly influences trust in tax authorities.

Hypothesis 1b: Perception of corruption significantly influences the power of tax authorities.

Hypothesis 2a: Perception of tax complexity significantly influences trust in tax authorities.

Hypothesis 2b: Perception of tax complexity significantly influences the power of tax authorities.

To investigate the associations between trust, power, voluntary compliance, and enforced compliance, two hypotheses are proposed:

Hypothesis 3: Trust in tax authority leads to voluntary compliance.

Hypothesis 4: The power of tax authority leads to enforced compliance.

Lastly, according to the SSF literature, trust enhances voluntary compliance while power induces enforced compliance. Yet, voluntary and enforced compliance are believed to end in overall tax compliance. Therefore, this study proposes two hypotheses as follow: Hypothesis 5: Voluntary compliance significantly influences overall tax compliance.

Hypothesis 6: Enforced compliance significantly influences overall tax compliance.

\section{DATA AND METHODOLOGY}

In this study, mixed methods research is used by concurrently applying a quantitative approach (a survey of individual taxpayers and a qualitative approach (semi-structured interviews with individual taxpayers and tax officers). The survey questionnaire is intended to identify the relationship of tax compliance factors (in this study, perception of corruption and perception of tax complexity) with trust and power. Meanwhile, the interviews provide more explanation about the factors and capture issues that the survey might not obtain.

The survey was conducted face-to-face with selected individual taxpayers in Jakarta, Indonesia, between March and April 2017. Jakarta is considered an appropriate place for choosing the respondents. It is the capital city of Indonesia, where more than ten million people with different income levels, religion, ethnicity, and culture reside. A total of 500 individual taxpayers were randomly involved as the survey participants when they visited several selected tax offices to lodge their tax return.

The questionnaire used in this study consists of five sections. Section A consists of questions on respondent compliance behaviour. Section B investigates the respondents' perceptions and opinions about tax compliance factors. Section C focuses on the respondents' perceptions and views on trust in and the power of the tax authority. Section D investigates perceptions and 
opinions about voluntary and enforced tax compliance. And the last section, Section E, collects data on respondents' demographic background.

From 500 questionnaires distributed, 453 completed (90.6\% of response rate). Next, the returned questionnaires were further used for the analysis of the study. Table 4.1 below shows the demographic background of the respondents.

Table 1 Background of Respondents

\begin{tabular}{|c|c|c|}
\hline Gender & Frequency & Per cent \\
\hline male & 259 & 54.4 \\
\hline female & 203 & 42.6 \\
\hline Total* $^{*}$ & 462 & 97.1 \\
\hline Missing & 14 & 2.9 \\
\hline Total & 476 & 100.0 \\
\hline Age & Frequency & Per cent \\
\hline under 20 & 11 & 2.3 \\
\hline $20-29$ & 146 & 30.7 \\
\hline $30-39$ & 127 & 26.7 \\
\hline $40-49$ & 91 & 19.1 \\
\hline $50-59$ & 65 & 13.7 \\
\hline 60 or more & 22 & 4.6 \\
\hline Total* & 462 & 97.1 \\
\hline Missing & 14 & 2.9 \\
\hline Total & 476 & 100.0 \\
\hline Relationship Status & Frequency & Per cent \\
\hline not married & 135 & 28.4 \\
\hline married & 311 & 65.3 \\
\hline divorced or widow & 16 & 3.4 \\
\hline Total* & 462 & 97.1 \\
\hline Missing & 14 & 2.9 \\
\hline Total & 476 & 100.0 \\
\hline Educational Attainment & Frequency & Per cent \\
\hline primary school & 1 & .2 \\
\hline high school & 176 & 37.0 \\
\hline diploma & 86 & 18.1 \\
\hline undergraduate & 170 & 35.7 \\
\hline master or PhD & 27 & 5.7 \\
\hline Total $^{*}$ & 461 & 96.8 \\
\hline Missing & 16 & 3.4 \\
\hline Total & 476 & 100.0 \\
\hline
\end{tabular}


Amongst the respondents, 54 per cent reported their gender as male, 43 per cent as female, while 3 per cent did not reveal their gender. Regarding age, two per cent of the respondents were under 20 years old, 31 per cent were between 20 and 29 years old; 27 per cent between 30 and 39; 19 per cent between 40 and 49; 14 per cent between 50 and 59; 4 per cent above 60 years old; and 3 per cent did not indicate their age. Regarding their marital status, 28.5 per cent of the respondents were single, 65 per cent married, 3.5 per cent divorced or widowed, and 3 per cent did not indicate their status. Meanwhile, regarding their level of education, one respondent had primary school as the highest level of educational attainment, 37 per cent had a high school level of education, 18 per cent had a diploma, 36 per cent had a bachelor's degree, and 6 per cent had completed a master or doctorate degree. The other 3 per cent did not reveal their educational attainment.

For analysing the data, the SPSS software is used to get the descriptive statistics, while Smart PLS 2.0 is used to examine the hypotheses. The SPSS software is used to get the basic statistical measures such as minimum and maximum values, mean and standard deviation of each indicator and variable. Next, following the recommendations from Hair, Black, Babin, and Anderson (2014) and the suggestion from Hair, Ringle, and Sarstedt (2011), measurement model evaluation and structural model results were gained using a partial least squares (PLS)-SEM technique by applying the SmartPLS software. Their validity and reliability were secured to guarantee the quality of measures and constructs used in the study.

Meanwhile, to get a deeper understanding of the relationships between the perception of corruption, perception of tax complexity, trust, power, and tax compliance and how the change in financial information access has associations with these two factors, semi-structured interviews towards several taxpayers and tax officers were conducted. 11 taxpayers and 18 tax officers participated in the discussions, which were conducted between March and May 2017.

Interview participants from the taxpayer group came from survey respondents who expressed a willingness to be involved more in the study and agreed to be interviewed. Meanwhile, in selecting participants from the tax office, purposive sampling and snowball sampling methods were used to get information-rich participants. The participants consisted of senior and middle managers in DGT's head office and local tax offices. The involvement of officers from the head office and local offices is intended to gain insights from both strategic and operational perspectives.

The interviews were conducted face-to-face or via telephone and take approximately one hour for each. Even though the law on financial information access was enacted not long ago, it is interesting to find out thoughts and expectations on the impact of this law on tax compliance.

Finally, in the interpretation phase 
of this study, a triangulation technique is applied where the two sets of findings gained from each quantitative (survey) and qualitative (interview) component are combined and integrated.

\section{RESULTS AND DISCUSSIONS}

From the survey, as can be seen from Table 5.1 below, the results show that perception of corruption has a moderate influence on trust in tax authorities with a path coefficient of -0.084 at the 0.10 significance level, which means acceptance of hypothesis 1a. The path coefficient's negative value demonstrates that perception of corruption had a significant but negative influence on trust in tax authorities. Interestingly, the result shows that perception of corruption had a positive effect on the power of tax authorities, which leads to the acceptance of hypothesis $1 \mathrm{~b}$. It means that the higher taxpayers' perception of corruption, the higher their perception of power of tax authorities. This result contrasts with the negative effect of perception of corruption on trust in tax authorities when the higher perception of corruption, the lower the trust in tax authorities.

\section{The association between} perception of tax complexity and trust had the same pattern as the perception of corruption. With a path coefficient of -0.156 at a 0.01 significance level, perception of tax complexity had a significant but negative influence on trust in tax authorities. Based on this result, hypothesis $2 a$ (perception of tax complexity significantly influences trust in tax authorities) was accepted. The negative path coefficients of perception of corruption and perception of tax complexity on trust in tax authorities indicate that an increase in perception of corruption and perception of tax complexity is associated with a decrease in trust in tax authorities, which are unsurprising results. On the other hand, perception of tax complexity seemed to have no significant influence on power of tax authorities, resulting in the rejection of hypothesis 2b, which states that 'perception of tax complexity significantly influences the power of tax authorities'. The complete results of the study can be seen in Table 5.1 below.

Table 5.1 Path Coefficients, T-statistics and Significance Level of the Model

\begin{tabular}{|c|c|c|c|}
\hline Propositions & $\begin{array}{c}\text { Path } \\
\text { Coefficient }\end{array}$ & T Statistics & Sig. Level \\
\hline Effects on Trust & & & \\
\hline Corruption & -0.084 & 1.798 & 0.073 \\
\hline Complexity & -0.156 & 3.081 & 0.002 \\
\hline Effects on Power & & & \\
\hline Corruption & 0.118 & 2.145 & 0.033 \\
\hline Complexity & -0.050 & 1.097 & Not sig. \\
\hline Effect on Voluntary & & & \\
\hline Compliance & & & \\
\hline Trust & 0.243 & 4.884 & 0.000 \\
\hline Effect on Enforced Compliance & & & \\
\hline Power & -0.070 & 1.315 & Not sig. \\
\hline Effects on Overall Compliance & & & \\
\hline Voluntary Compliance & 0.259 & 5.607 & 0.000 \\
\hline Enforced Compliance & -0.180 & 3.908 & 0.000 \\
\hline
\end{tabular}

For the associations between trust, power, voluntary compliance, and enforced compliance, the results show that trust has a significant influence on voluntary compliance with a path coefficient of 0.243 , resulting in acceptance of hypothesis 3, which states that 'trust in tax authorities leads on voluntary compliance'. On the contrary, 
with a path coefficient of -0.070 , power has no significant influence on enforced compliance suggesting rejection of hypothesis 4.

\section{Regarding the associations} between voluntary compliance, enforced compliance, and overall tax compliance, both voluntary compliance and enforced compliance significantly impact overall tax compliance with path coefficients of 0.259 and -0.180 , respectively. From these path coefficients, voluntary compliance positively influenced overall tax compliance, while enforced compliance negatively influences overall tax compliance. This result can be read as the higher the compliance enforced, the lower the overall compliance. Therefore, hypothesis 5 and hypothesis 6 were accepted.

From the interview, the discussion by taxpayers reveals that most participants perceived that corruption cases were likely to damage their sense of justice and thus affect their willingness to pay tax. Regardless of whether the corruption happened within the tax authority or in other government institutions. On the other hand, participants from the tax office group have mixed opinions. Some of them agreed that perception of corruption significantly affects taxpayers' willingness to pay tax. However, some others argued that sound systems in the tax authority could be used to maintain the compliance level, regardless of whether the corruption exists or not.

Interesting findings come in the interview regarding the association between perception of tax complexity and power. While the survey results indicate no significant association between perception of tax complexity and power of tax authorities, the interview results reveal that tax complexity is partly associated with the inability of the tax authority in executing its legitimate power, which means it has to use its coercive power. The tax authority's failure to enforce its legitimate power (fully access taxpayers' data, for example) is likely to lead the tax authority to implement a coercive power (request more data from taxpayers and require taxpayers to follow additional procedures).

Furthermore, the interview results indicate that enacting law on financial information access affects taxpayers' perception of corruption and perception of tax complexity. Taxpayers are likely to comply with tax as long as they believe that the tax authority has full access to their business data and information. Moreover, when the tax authority knows the entire economic situation of taxpayers, taxpayers can no longer hide their financial situation because there is no asymmetric information between taxpayers and tax officers. There is no more chance and opportunity to cheat between taxpayers and tax officers with transparent and symmetrical information, no more room for corruption. As a result, the perception of corruption will be more positive.

Regarding the perception of tax complexity, interview participants believe that the complexity in fulfilling tax obligation amongst taxpayers is partly caused by the tax authority's inability to obtain 
comparable data from other parties for check and balance purposes. This inability is believed as the root of tax complexity as it forces the tax authority to ask for more data from taxpayers. Therefore, with full access to financial data, the tax office will require fewer data and documents from taxpayers, which will significantly simplify it. Interview participants also believe that if financial data is opened widely for tax purposes and the tax authority can easily see the complete profile of the taxpayer's finances, it will change the compliant behaviour without the need for enforcements. When all systems can detect all taxpayer's transactions, it would force them to comply voluntarily.

\section{CONCLUSION}

This study examines two tax compliance factors, perception of corruption and perception of tax complexity, associated with trust in tax authorities and power of tax authorities using a survey questionnaire towards individual taxpayers in Jakarta, Indonesia. Descriptive analysis was gained by using SPSS, while structural model results were acquired by using Partial Least Square (PLS)-SEM technique.

In the structural model evaluation, the survey results indicate that perception of corruption had a negative and significant association with trust in the tax authority and a positive and significant association with the power of tax authorities Meanwhile, similar to the perception of corruption, the survey results demonstrate that the perception of tax complexity had a negative and significant association with trust in the tax authority. However, the survey results indicate that there is no sufficient evidence showing perception of tax complexity had a significant association with power of tax authorities.

The results also show that trust has a significant influence on voluntary compliance. However, the study indicates that power has no significant influence on enforced compliance. Meanwhile, voluntary compliance (positively) and enforced compliance (negatively) significantly impact overall tax compliance.

From the interview, the results show the associations between the enactment of the law on financial information access for tax purposes and these two factors. This law's enactment is believed to reduce corruption practices as it will minimise asymmetrical information between taxpayers and the tax authority. When taxpayers realise that the tax authority has access to their financial data, it will make them comply with taxes voluntarily without the need for enforcement. Moreover, the improvement in accessing taxpayers' financial data is believed to reduce the tax system's complexity as the tax authority will require fewer data and documents from taxpayers.

However, since the law was enacted not long ago, this study has limitations in addressing the comprehensive impact of enacting this law on long-term tax compliance. Therefore, future research is suggested to comprehensively study the effect of the 
law on overall tax compliance. It will also be interesting to duplicate this study using taxpayers' data collected by the tax authority to get a more reliable picture of their compliance.

\section{REFERENCES}

[1] Andreoni, J., Erard, B., \& Feinstein, J., (1998). Tax compliance. Journal of Economic Literature, 36(2), 818-860. http://www.jstor.org/stable/2565123

[2] Bardach, E., \& Kagan, R. A. (1982). Going by the book: The problem of regulatory unreasonableness. Philadelphia: Temple University Press.

[3] Bird, R. M., \& Martinez-Vazquez, J. (2008). Tax effort in developing countries and high income countries: The impact of corruption, voice and accountability. Economic Analysis \& Policy, 38(1), 54-71. https://doi.org/10.1016/S0313-5926(08)50006-3

[4] Carter, L. H. (1979). Reason in law. Boston: Little Brown.

[5] DGT. (2017). Laporan Kinerja Direktorat Jenderal Pajak. Jakarta: DGT.

[6] Doig, A., \& Theobald, R. (1999). Introduction: Why corruption?. Commonwealth \& Comparative Politics, 37(3), 1-12. https://doi.org/10.1080/146620499084477

[7] Feld, L. P., \& Torgler, B. T. D. B. (2008). Coming closer? Tax morale, deterrence and social learning after German unification. CREMA Working Paper Series 2008-09, Center for Research in Economics, Management and the Arts (CREMA).

[8] Gangl, K., Hofmann, E., \& Kirchler, E. (2015). Tax authorities' interaction with taxpayers: A conception of compliance in social dilemmas by power and trust. New Ideas in Psychology, 37, 13-23. https://doi.org/10.1016/j.newideapsych.2014.12.001

[9] Gangl, K., Hofmann, E., Pollai, M., \& Kirchler, E. (2012). The dynamics of power and trust in the 'Slippery Slope Framework' and its impact on the tax climate. http://dx.doi.org/10.2139/ssrn.2024946
[10] Gobena, L. B., \& Dijke, M. V. (2016). Power, justice, and trust: A moderated mediation analysis of tax compliance among Ethiopian business owners. Journal of Economic Psychology, 52, 24-37. https://doi.org/10.1016/j.joep.2015.11.004

[11] Hair, J. F., Black, W. C., Babin, B. J., \& Anderson, R. E. (2014). Multivariate data analysis, 7 th edition. London, The United Kingdom: Pearson Education Limited.

[12] Hair, J. F., Ringle, C. M., \& Sarstedt, M. (2011). PLS-SEM: Indeed a silver bullet. Journal of Marketing Theory and Practice, 19(2), 139-152. https://doi.org/10.2753/MTP10696679190202

[13] Hofmann, E., Gangl, K., Kirchler, E., \& Stark, J. (2014). Enhancing tax compliance through coercive and legitimate power of tax authorities by concurrently diminishing or facilitating trust in tax authorities. Law and Policy, 36(3), 290-313. https://doi.org/10.1111/ lapo.12021

[14] Hofmann, E., Hartl, B., Gangl, K., Hartner-Tiefenthaler, M., Kirchler, E. (2017). Authorities' coercive and legitimate power: The impact on cognitions underlying cooperation. Frontiers in Psychology, 1-15. https://doi.org/10.3389/fpsyg.2017.00005

[15] Kasper, M., Kogler, C., \& Kirchler, E. (2015). Tax policy and the news: An empirical analysis of taxpayers' perceptions of tax-related media coverage and its impact on tax compliance. Journal of Behavioral and Experimental Economics, 54, 58-63. https://doi.org/10.1016/j.socec.2014.11.001

[16] Kirchler, E., Hoelzl, E., \& Wahl, I. (2008). Enforced versus voluntary tax compliance: The 'slippery slope' framework. Journal of Economic Psychology, 29(2), 210-225. https://doi.org/10.1016/j.joep.2007.05.004

[17] Kogler, C., Muehlbacher, S., \& Kirchler, E. (2013). Trust, power, and tax compliance: Testing the "slippery slope framework" among self-employed taxpayers, Vienna: WU International Taxation Research Paper Series.

[18] Kogler, C., Muehlbacher, S., \& Kirchler, E. (2015). Testing the "slippery slope framework" among self-employed taxpayers. Economic of Governance,16(2), 
https://doi.org/10.1007/s10101-015-0158-9

[19] Lisi, G. (2012). Unemployment, tax evasion and the slippery slope framework. Munich Personal RePEc Archive (MPRA) Paper No. 37433, 1-7.

https://doi.org/10.1007/s12232-012-0165-x

[20] Mardhiah, M., Miranti, R., \& Tanton, R. (2019).

The slippery slope framework: Extending the analysis by investigating factors affecting trust and power. CESifo Working Paper No. 7494. https://ssrn.com/abstract $=3338850$

[21] Mas'ud, A., Manaf, N. A. A., \& Saad, N. (2014). Do trust and power moderate each other in relation to tax compliance?. Procedia - Social and Behavioral Sciences, 164, 49-54. https://doi.org/10.1016/j.sbspro.2014.11.049

[22] Melgar, N., Rossi, M., \& Smith, T. W. (2010). The perception of corruption. International Journal of Public Opinion Research, 22(1), 120-131. https://doi.org/10.1093/ijpor/edp058

[23] Mishler, W., \& Rose, R. (2001). What are the origins of political trust? Testing institutional and cultural theories in post-communist societies. Comparative Political Studies, 34(1), 30-62.

https://doi.org/10.1177/0010414001034001002

[24] Muehlbacher, S., \& Kirchler, E. (2010). Tax compliance by trust and power of authorities. International Economic Journal, 24(4), 607-610.

https://doi.org/10.1080/10168737.2010.526005

[25] Newman, N. (2011). Indonesia: Telling lies. World Policy Journal, 28(4), 82-91. https://doi.org/10.2307/41479308

[26] Prinz, A., Muehlbacher, S. ,\& Kirchler, E. (2014). The slippery slope framework on tax compliance: An attempt to formalisation. Journal of Economic Psychology, 40, 20-34. https://doi.org/10.1016/j.joep.2013.04.004

[27] Riahi-Belkaoui, A. (2008). Bureaucracy, corruption and tax compliance. In R. W. McGee (Ed.), Taxation and public finance in transition and developing economies (pp. 3-10). Miami, USA: Springer.

[28] Richardson, G. (2006). Determinants of tax evasion: A cross-country investigation. Journal of International Accounting, Auditing and Taxation, 15(2), 150-169. https://doi.org/10.1016/j.intaccaudtax.2006.08.005
[29] Richey, S. (2010). The impact of corruption on social trust. American Politics Research, 38(4), 676-690.

https://doi.org/10.1177/1532673X09341531

[30] Saad, N. (2011). Fairness perceptions and compliance behaviour: Taxpayers' judgments in self-assessment environments (PhD Thesis). University of Canterbury.

[31] Scholz, J. T. (1984). Voluntary compliance and regulatory enforcement. Law \& Policy, 6(4), 385-404. https://doi.org/10.1111/j.1467-9930.1984.tb00334.x

[32] Seligson, M. A. (2002). The impact of corruption on regime legitimate: A comparative study of four Latin America countries. The Journal of Politics, 64(2), 408-433.

[33] Siahaan, F. (2012). The influence of tax fairness and communication on voluntary compliance: Trust as an intervening variable. International Journal of Business and Social Science, 3(21), 191-198.

[34] Torgler, B. (2004). Tax morale, trust and corruption: Empirical evidence from transition countries. IN CREMA Working Paper No. 2004 - 05, Center for Research in Economics, Management and the Arts.

[35] Torgler, B. (2006). The importance of faith: Tax morale and religiosity. Journal of Economic Behavior \& Organization, 61(1), 81-109. https://doi.org/10.1016/j.jebo.2004.10.007

[36] Transparency-International. (2017). Corruption perceptions index 2017. TransparencyInternational. https://www.transparency.org/en/news/corruption-perceptions-index-2017

[37] Uslaner, E. M. (2005). Trust and corruption. In J. G. Lambsdorff, M. Taube, \& M. Schramm (Eds.), The new institutional economics of corruption (pp. 76-92). New York, USA: Routledge, http://dx.doi.org/10.4324/9780203413920

[38] Wahl, I., Kastlunger, B., \& Kirchler, E. (2010). Trust in authorities and power to enforce tax compliance: An empirical analysis of the "Slippery Slope Framework". Law \& Policy, 32(4), 383-406. https://doi.org/10.1111/j.1467-9930.2010.00327. 